\title{
VERY EARLY REMISSION AND INCREASED APOPTOSIS WITH THE USE OF PENTOXIFYLLINE IN CHILDREN WITH ACUTE LYMPHOBLASTIC LEUKEMIA
}

\author{
Violeta Salceda Rivera ${ }^{1}$, Pablo Ortiz-Lazareno ${ }^{2}$, Alejandro Bravo-Cuellar², Georgina \\ Hernández-Flores $^{2}$, Jesús Meza-Arroyo ${ }^{2}$, Monzerrat Pardo ${ }^{3}$, Ilse Delgado-Ruiz ${ }^{3}$, Hugo \\ Romo-Rubio $^{3}$, Feranando Sanchez-Zubieta ${ }^{3}$, and Ramón Oscar Gonzalez-Ramella ${ }^{3}$ \\ ${ }^{1}$ Universidad de Guadalajara Centro Universitario de Ciencias de la Salud \\ ${ }^{2}$ Centro de Investigación Biomédica de Occidente (CIBO), Instituto Mexicano del Seguro \\ Social (IMSS) \\ ${ }^{3}$ Hospital Civil de Guadalajara
}

November 16, 2020

\begin{abstract}
Background: Acute lymphoblastic leukemia (ALL) is the most common cancer in childhood, and despite advances in cancer treatment, there are still cases of relapse and death secondary to resistance to chemotherapy or apoptosis. One of the mechanisms is the activation of the IKK/NF- $\varkappa \mathrm{B}$ signaling pathway that leads to the expression of genes that interfere with apoptosis. Pentoxifylline (PTX) can block phosphorylation of $\mathrm{I} \varkappa \mathrm{B}$, thus preventing the NF- $\varkappa \mathrm{B}$ activity, therefore the activation of antiapoptotic genes. Procedure: Controlled versus placebo, randomized, double-blind clinical trial. Pediatric patients with ALL during induction therapy were assigned either to pentoxifylline or the placebo group. Bone marrow aspirates were performed on day-1, day-8, day-15, and day-22. We performed flow MRD, determination of apoptosis by annexin- $\mathrm{V} /$ propidium iodide test, and senescence by $\beta$-galactosidase activity. Results: PTX group had higher percentage of apoptotic cells on day-8 (41.3\% vs $19.4 \%, \mathrm{p}=0.029)$, and day-15 (35.0\% vs $14.2 \%, \mathrm{p}<0.01)$. No difference was observed in the senescence determinations. On day-8, the PTX group showed MRD of $0.25 \%$ vs $18.2 \%$ ( $<<0.01)$ in the placebo group; at day-15 the PTX group showed MRD of $0.09 \%$ vs $1.4 \%(\mathrm{p}=0.02$ ). Patients with MRD $<0.01 \%$ at day- 8 had 3 -year OS of $81.6 \%$ vs $58.3 \%$ ( $\mathrm{p}=0.03$ ); at day-15 patients with MRD $<0.01 \%$ at day- 8 had 3 -year OS of $77.9 \%$ vs $54.5 \%(\mathrm{p}=0.03$ ). Conclusion: PTX group showed a MRD $<0.01 \%$ earlier, on day- 8 and 15 , and presented a higher percentage of apoptotic cells. In the entire cohort, patients with MRD $<0.01 \%$ on day 8 or 15 showed better OS.
\end{abstract}

\section{Hosted file}

Pentoxifylline in acute lymphoblastic leukemia.pdf available at https://authorea.com/users/ 376176/articles/493235-very-early-remission-and-increased-apoptosis-with-the-use-ofpentoxifylline-in-children-with-acute-lymphoblastic-leukemia

\section{Hosted file}

TABLE 1.pdf available at https://authorea.com/users/376176/articles/493235-very-earlyremission-and-increased-apoptosis-with-the-use-of-pentoxifylline-in-children-with-acutelymphoblastic-leukemia

\section{Hosted file}


TAble_2.pdf available at https://authorea.com/users/376176/articles/493235-very-earlyremission-and-increased-apoptosis-with-the-use-of-pentoxifylline-in-children-with-acutelymphoblastic-leukemia

\section{Hosted file}

TABLE 3.pdf available at https://authorea.com/users/376176/articles/493235-very-earlyremission-and-increased-apoptosis-with-the-use-of-pentoxifylline-in-children-with-acutelymphoblastic-leukemia

A

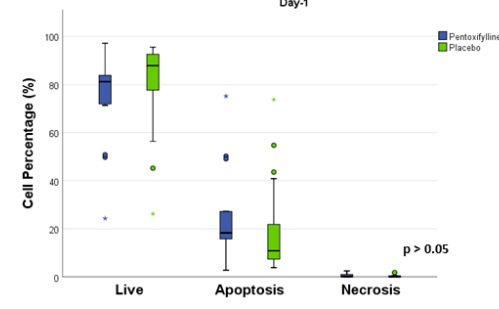

C

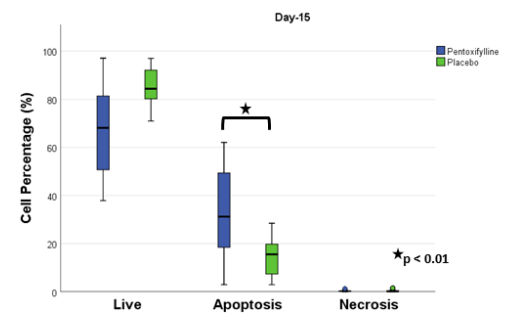

B

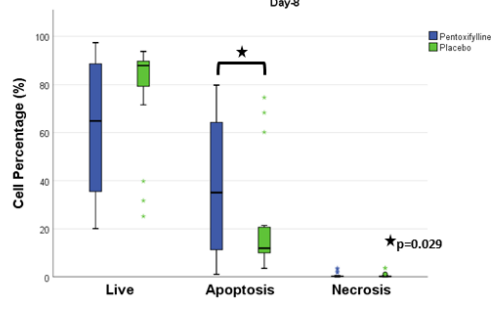

D

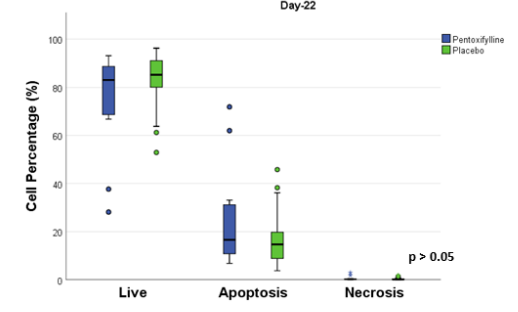


A

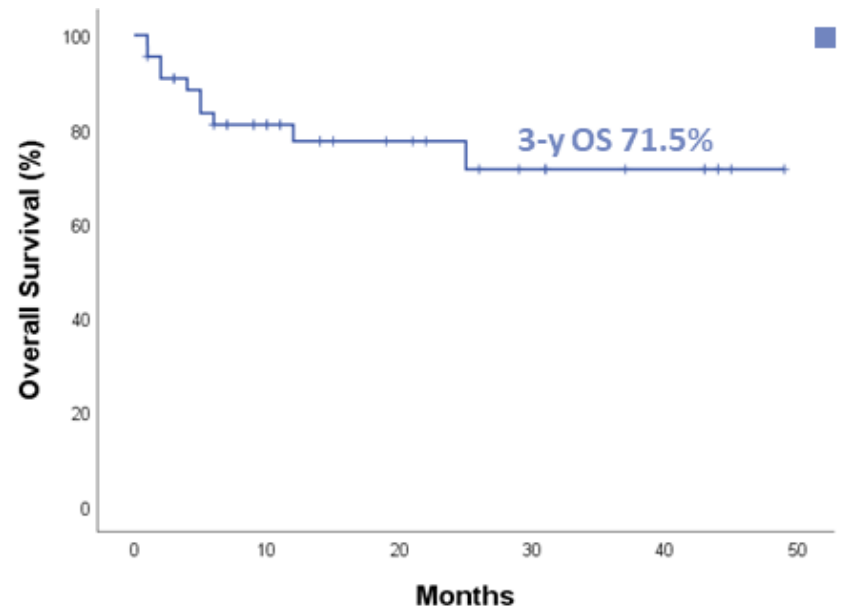

B

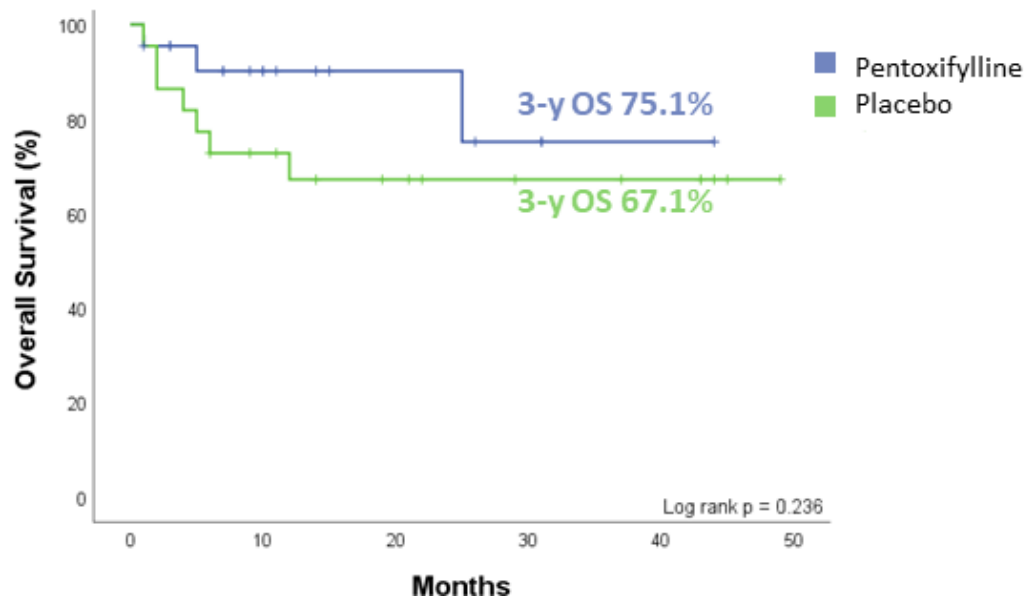


A

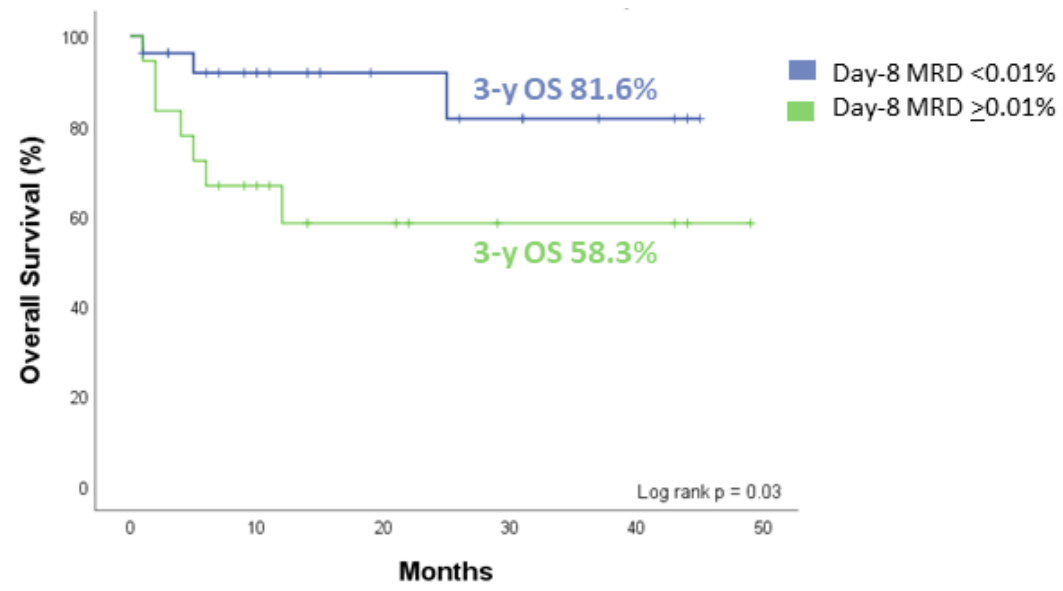

B

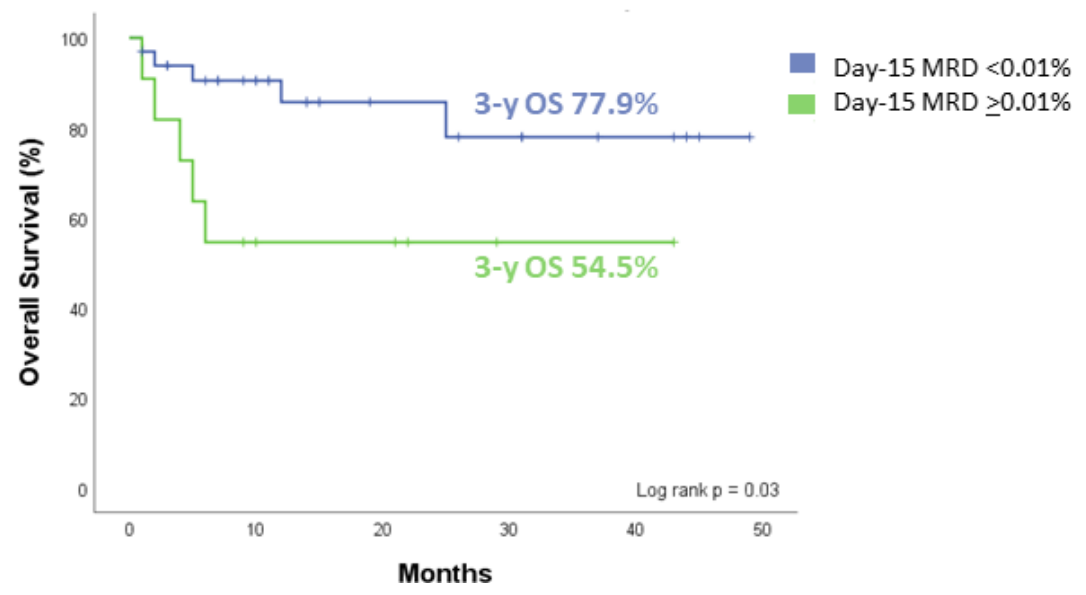

